\title{
The C-BIM Model in Improving Reading, Writing, and Critical Thinking Skills: Outcome and Perception
}

\author{
${ }^{1}$ Haerazi, ${ }^{2}$ Sadaf Dehghani, ${ }^{3}$ Umi Rachmawati, ${ }^{4 *}$ Dedi Irwansyah \\ ${ }^{1}$ English Language Education, FBMB, Universitas Pendidikan Mandalika, Jl. Pemuda No. 59A, \\ Mataram 83125, Indonesia \\ ${ }^{2}$ Economics and Administrative Science, Allameh Mohades University, St: Mazandaran, Nur city, Iran \\ ${ }^{3}$ Manajement Studi Program, Universitas Muhammadiyah Magelang, Kampus 1, Jln. Tidar No. 21 \\ Magelang, Indonesia \\ ${ }^{4}$ English Language Education Program, IAIN Metro, Jl. Ki Hajar Dewantara 15A Kampus Kota Metro \\ - Lampung 34112, Indonesia
}

*Corresponding Author e-mail: dedi.irwansyah@metrouniv.ac.id

Received: May 2021; Revised: June 2021; Published: July 2021

\begin{abstract}
This study investigates the culture-based instructional materials (C-BIM) model to improve students' reading and writing skills viewed from critical thinking skills at the junior-high-school in Indonesia. This study is a mixed-method employing the explanatory sequential design. The data are in the form of quantitative and qualitative data. The quantitative data are collected first and followed by the quantitative one. The research instruments are in the form of reading and writing tests, questionnaires, and interview sheets. The test is used to see the students' reading and writing achievements. Meanwhile, the questionnaire is utilized to determine the students' and teachers' intercultural awareness and perception of incorporating cultures in teaching materials. The data of reading-writing achievement are analyzed using descriptive and inferential statistics. Thus, the data of students' and teachers' cultural awareness and perception are gained by applying qualitative steps: analysis, reduction, coding, interpretation, and conclusion. Based on the result of the research, this study indicates that the C-BIM model significantly affects students' reading and writing skills. Also, it has an interaction between teaching materials and critical thinking skills. Researchers elaborate on those in the discussion part of this article regarding the students' intercultural competence and perception.
\end{abstract}

Keywords: critical thinking skills; reading and writing skills; teaching materials

How to Cite: Haerazi, H., Dehghani, S., Rachmawati, U., \& Irwansyah, D. (2021). The C-BIM Model in Improving Reading, Writing, and Critical Thinking Skills: Outcome and Perception. Jurnal Penelitian Dan Pengkajian Ilmu Pendidikan: E-Saintika, 5(2), 152-167. https://doi.org/10.36312/esaintika.v5i2.503

\section{INTRODUCTION}

The Indonesian curriculum (K13) demands English teachers at junior high schools to develop students' higher-order thinking (HOT) skills. One of the HOT skills is critical thinking skills (Haerazi et al., 2020). English teachers at junior high schools should be able to develop their teaching materials that can improve students' HOT skills with learning activities. To achieve the learning goal, English teachers are also demanded to find out appropriate ways to teach. Critical thinking skills require students to "analyze and evaluate learning activities and justify conclusions" (Manshaee et al., 2014; Thompson \& Patterson, 2019). It is in line with Wei (2014), who 
states that critical thinking is a habit of mind to analyze and gauge evidence and confirm conclusions. The learning skills of conceptualizing, analyzing, synthesizing, and evaluating, and justifying conclusions are promoted when students have both opportunities and requirements for reflections in the classes (Tan et al., 2017). To provide students with reflective learning activities, English teachers developed culture-based instructional materials in the ELT classes. The language skills addressed by this study were reading and writing skills.

Critical thinking skills can help learners organize how they have to learn smoothly. In EFL classes, some researchers conducted some studies about these. The results show that these skills have an effect on ELT students' language skills and achievement. Liu and Stapleton (2018) argue that critical thinking skills help students to think effectively in writing an essay composition, lexical items, paragraph organization, and meta-discourses. Yuan and Stapleton (2020) declare that critical thinking can help learners monitor their learning achievement in classes. In his study, Ab-Kadir (2018) vividly indicates that these skills help students and teachers navigate their creativity. Espey (2018) informs these skills also can enhance students' academic achievement. Also, Low, Hui, and Cai (2017) note that it improves pre-service teachers' professional and pedagogical knowledge.

Given that the essential role of critical thinking skills, this study was designed to develop students' critical thinking skills in order to improve their reading and writing skills. These skills are two of the language skills necessary to improve (Haerazi \& Irawan, 2020b). Reading and writing skills interplayed with each other. The more you read, the more insights you have to write (Haerazi et al., 2019). Unfortunately, most students have a negative attitude towards reading (Wiles et al., 2016). Compared to reading skills, students necessitate a little hard work to attain writing skills because becoming a good writer requires more cognitive use, linguistics competence, and cultural dimensions (Haerazi \& Irawan, 2020a). Therefore, this study provides students with interesting insights to facilitate them with reading activities continued by writing exercises. It is done through developing culture-based instructional materials. To attain this goal, the researchers initially developed culture-based instructional materials for reading and writing classes.

In reading, students still faced some difficulties such as having inadequate vocabulary mastery, determining an idea of paragraphs, comprehending paragraphs, inadequate grammatical knowledge and having low motivation to read (Sumekto, 2018; Novita, 2018; \& Nerim, 2020). In addition, the teaching of reading in the Indonesian middle schools still is oriented to intensive reading (IR) and not too extensive reading (ER). IR tends to involve students in activities to obtain detailed meaning, to increase reading skills, and to develop vocabulary and grammar knowledge (Januarty, 2018). In ER activities, students are directed to understand the meaning rather than the language itself. For teaching reading, ER and IR should not be designed as being in opposition, as the two serve different but complementary reading purposes (Chen, 2018).

In EFL classes, reading and writing interplayed. It is in line with Rahmawati (2019), who states that the reading and writing should not be seen as being in opposition in which the more the learners are exposed to the reading activities, the more the learners are able to write in such a way. In writing, students are demanded to produce and compose some academic or non-academic outputs as their writing products. That's why much more reading activities can be very beneficial for them to 
be habituated to read. The students, then, are expected to recognize how the texts are in terms of its structures, grammar, punctuations, capitalization, and mechanics. By knowing these linguistic features, students are able to write such the text being read later on in an appropriate way (Listyani, 2017). In this study, the English texts provided for students to read are cultural texts. The given texts are the adapted, modified, and authentic texts. It aims to give an opportunity for them to internalize and imitate the linguistic features and cultural dimensions of the texts.

The cultural topics to read in this study are to help students utilize their prior knowledge while reading. By giving local interesting cultural topics, students feel easy to comprehend the texts because they have recognized the content of the texts. The culture-based materials are designed to enable students to read and write successfully. Before going to write, students are asked to do reading activities. It can be called by preparing before reading. According to Albiladi (2018), preparing before reading is to conduct a more extensive exploration of the overall aspects of the texts, and students should understand the topic of the text and the sequences of the story from the text. To make it easy to do, teachers can help students with giving a summarization of the text. Afterward, students are involved in detail reading activities. It aims to lead students to read a short passage within sentence-by-sentence.

In measuring the students' reading activities, the students are asked to create sentences based on the cultural topics. These activities intensify the identification and discussion of phrase meanings and wordings during the detailed reading. It enables students to create sequences of meaningful sentences. Students can also take greater control of the reading and writing activities, both in groups and individually. In the discussion group, students are able to practice thinking critically about what they are reading. Individually, students are supported to practice writing long and meaningful text fluently. As a result, critical thinking skills in critical reading become the best practice for students to write. It is in accordance with Haryati and Hidayati (2017) who state that the critical reading activities can be seen from learning activities in the class in which students learn how to comprehend explicitly reading texts and identify the texts, including language functions and contents, whether in discussion groups and individually.

Insertion of culture-based materials in the teaching of reading and writing helps students think critically, and it starts from their own cultures. Cultural topics provided include traditional rites, traditional games, local traditional arts, and local literacies. According to Dinh and Sharifian (2017), integrating local cultures into EFL teaching materials can raise students' cultural concepts and cultural practice awareness. It also permits them to discuss and talk about cultural conceptualizations, encourage intercultural contacts, and promote their cultures and cultural identities. It is supported by McConachy and Hata (2013); and McConachy (2018) who state that culture-based EFL materials encourage students to reflect their own cultures into their cultural practices, whether orally or written. The culture-based EFL materials can develop a critical cultural and linguistic consciousness (H. Song, 2013). It can also help students develop their intercultural competencies and linguistics awareness (Shin et al., 2011).

Considering that culture-based instructional materials are essential, this study aims to develop culture-based materials for students who learn reading and writing skills at the junior high schools, Indonesia. This study's novelty lies on the utilization of critical thinking skills by inserting culture-based materials to improve students' 
reading and writing skills. Critical thinking is measured as the attribute variable which marks students' reading and writing skills. In facilitating students to engage in reading activities and writing exercises, this study is initially started by administering the reading and writing tasks and cultural topics to improve students' critical thinking skills.

\section{METHOD}

\section{Research Design}

This study aimed at investigating the quality of culture-based instructional materials (C-BIM) model to improve students' reading and writing skills in relation to students' critical thinking skills at the middle schools of central Lombok, West Nusa Tenggara, Indonesia. This study was classified as a mixed-method using the explanatory sequential design. This design was used to elaborate and explain the research data based on the research problems (Creswell \& Creswell, 2018). The data consisted of quantitative and qualitative data. The process of collecting data was started from quantitative data and then the qualitative data. In this study, the qualitative data here were collected to support, explain, and elaborate the quantitative findings. The quantitative data comprise the students' reading and writing achievement after practicing the culture-based instructional materials at the middle schools. It was conducted in an experimental study. To support these data, the researchers conducted an interview based on the questionnaire results. Meanwhile, the qualitative data comprise the students' and teachers' intercultural awareness and perception of incorporating cultures into ELT materials.

This study involved 10 English teachers and 350 students at the middle schools at Central Lombok, West Nusa Tenggara, Indonesia. The ten English teachers are involved in the interview sessions and filling questionnaire items to find their intercultural awareness and perception on incorporating local and target cultures in their teaching materials (EFL textbooks). Also, 350 students were invited to fill a questionnaire of their responses towards implementing the culture-based instructional materials (C-BIM). To find the quality of the C-BIM model, the researchers employed an experimental study using an inequivalent control group design. In doing so, the researcher decided the middle schools at SMPN 1 Jonggat as a place for the field testing. The students there consisted of two classes in which each class comprised 29 students. One class was subjected to an experimental type using the C-BIM model, and the second class was treated as the control class using the existing teaching materials.

\section{Research Instruments}

The data of this study included quantitative and qualitative data. The instruments of collecting the quantitative data used reading tests, writing tests, critical thinking tests, questionnaires, and interview sheets. Reading tests aimed to know the students' reading skills, while writing tests were used to determine students' writing skills after being treated using the C-BIM model. The reading test consists of 25 items indicating critical thinking aspects, in which the topics are related to cultural topics. They were asked to read two reading texts and each text comprised 10-15 questions. During the reading activities, students also were invited to make sentences based on the reading texts. These sentences made would be used to do writing tests. In the writing test, they were asked to compose a descriptive text in line with cultural topics such as traditional arts, traditional rites, traditional games, and traditional 
technologies. In writing tests, students were completed with graphic organizers. Regarding the critical thinking tests, students were prepared an additional question in the reading and writing questions. It was intended to see how students utilized and applied their critical thinking skills during reading and writing activities.

The instrument of questionnaires was used to collect the students' and teachers' intercultural awareness and perception on incorporating cultures into their ELT materials. The questionnaire then was underpinned by doing interview activities. The interview guidelines of intercultural awareness consisted of 13 questions that illustrate how students and teachers had a cultural insight and cultural competencies, whether local cultures or target cultures. Thus, the questionnaire of perception consisted of 12 substances relating to implementing the C-BIM model in the teaching of reading and writing skills at the middle schools. The questionnaires were distributed to them after doing treatments at the experimental group. In this study, the instruments (tests and questionnaires) were stated as valid and reliable instruments based on the statistical analysis and content validity.

\section{Data Analysis Technique}

The current research data were analyzed quantitatively and qualitatively. The quantitative data were computed using descriptive and inferential statistical analysis. The descriptive statistical analysis was used to find out mean, median, mode, and standard deviation toward students' reading achievement, writing scores, and critical thinking skills in both experimental and control classes. Meanwhile, the inferential statistical analysis aimed to find out normality distribution, homogeneity of variance, and multifactor analysis of variance. The normality distribution was found using the One-Sample Kolmogorov-Smirnov analysis formula. It was said as a normal distribution because the significant probability was higher than the sig. level 0.05 . Thus, the homogeneity test was made using the Levene test formula. The data were stated as homogeneous data because the sig. probability was greater than the sig. level 0.05. In an attempt to answer the research hypotheses, this study employed multifactor analysis of variance (ANOVA) using two-way ANOVA. The conclusion of this was made where Ha (alternative hypotheses) was accepted at the sig. level 0.05. It was computed by employing IBM SPSS 22 devices.

Dealing with the qualitative data, researchers conducted the data collection after the quantitative data collection. This study's qualitative data are related to the data of students' and teachers' intercultural awareness and perception on culture-based materials. The data were processed using qualitative steps: analysis, reduction, coding, interpretation, and conclusion (Cohen et al., 2018). The results of intercultural awareness and perception were analyzed and categorized in line with the research problems. Data were then lessened and coded into two types: students' and teachers' perception and teachers' intercultural awareness. To make more robust data, the researchers interpreted and discussed data in more detail. In the last step, the obtained data were concluded with a brief explanation of the students' and teachers' perception and teachers' intercultural awareness in incorporating cultures in their ELT materials.

\section{RESULTS AND DISCUSSION}

\section{Research Findings}

The place of cultures in EFL instructions has been a complex issue. Designing various instructional methods and models to teach is conducted. One of those efforts is incorporating local cultures and target cultures in EFL textbooks. This study tried 
to investigate; (1) the quality of the C-BIM model to improve students' reading and writing skills viewed from critical thinking skills at junior high schools, West Nusa Tenggara, Indonesia; (2) the teachers' intercultural awareness and students' and teachers' perception on inserting cultural materials to improve students' reading and writing skills in relation to critical thinking skills. In this study, issues of the C-BIM model are elaborated quantitatively, while issues of the English teachers' intercultural awareness and students' and teachers' perception of the C-BIM model are exposed qualitatively.

\section{Research question 1: the effectiveness of the C-BIM model}

Many studies show that culture-based materials can improve students' speaking skills (Fernández-Agüero \& Chancay-Cedeño, 2019; Aprianoto \& Haerazi, 2019), reading skills (Hoff, 2019), and writing skills (Haerazi et al., 2018). Also, providing students with cultural activities can evolve students' cultural and intercultural awareness (McConachy, 2018; Kusumaningputri \& Widodo, 2018), multicultural insight (Uzum et al., 2018), and linguistic awareness (Krulatz et al., 2018). To attain the research results, researchers start from the development process in this current study to find out the quality of the C-BIM model. Thus, teaching materials of reading and writing skills are developed in accordance with the current curriculum at the junior high schools.

The existing teaching materials are inserted cultures, local cultures and target cultures. Based on the previous need analysis results, the nominated cultures are in the form of traditional arts, traditional games, traditional rites, traditional technologies, and local literacies. These various cultures are then distributed in different texts for reading activities, such as texts containing local and target cultures. The reading activities are designed in 10-15 tasks with different learning goals. Meanwhile, the writing practices are designed in 10 learning tasks. The researchers monitor the instructional goals, inputs, teachers' and students' roles, and classroom management before applying the C-BIM model. It is conducted in 4-5 meetings. Table 1 shows the students' average scores in the experimental and control class. Thus, the multifactor analysis of variance (ANOVA) is carried out.

Table 1. Results of students' achievement in the experimental and control classes

\begin{tabular}{|c|c|c|c|c|c|}
\hline \multirow{3}{*}{ Skills } & \multirow{3}{*}{$\begin{array}{c}\text { Groups and } \\
\text { Level }\end{array}$} & \multirow{3}{*}{ Mean } & \multirow{3}{*}{ Std. Error } & \multicolumn{2}{|c|}{$95 \%$ Confidence Interval } \\
\hline & & & & Lower & Upper \\
\hline & & & & Bound & Bound \\
\hline \multirow{2}{*}{ Reading Skills } & C-BIM Model & 72.183 & 1.961 & 68.247 & 76.118 \\
\hline & Non-Culture & 61.596 & 1.938 & 57.707 & 65.485 \\
\hline \multirow{2}{*}{ Writing Skills } & C-BIM Model & 75.593 & 1.568 & 72.446 & 78.739 \\
\hline & Non-Culture & 65.553 & 1.549 & 62.445 & 68.662 \\
\hline \multirow{3}{*}{$\begin{array}{l}\text { Critical Thinking } \\
\text { Level in Reading } \\
\text { Classes }\end{array}$} & High & 75.834 & 2.006 & 71.809 & 79.860 \\
\hline & Medium & 65.333 & 2.195 & 60.928 & 69.739 \\
\hline & Low & 59.500 & 2.874 & 53.732 & 65.268 \\
\hline \multirow{3}{*}{$\begin{array}{l}\text { Critical Thinking } \\
\text { Level in Writing } \\
\text { Classes }\end{array}$} & High & 78.205 & 1.603 & 74.987 & 81.422 \\
\hline & Medium & 67.597 & 1.755 & 64.076 & 71.119 \\
\hline & Low & 65.917 & 2.298 & 61.306 & 70.527 \\
\hline
\end{tabular}

The data of reading, writing, and critical thinking skills in the experimental class was greater than in the control class. This indicates the C-BIM model is more effective than non-C-BIM model in improving students' reading and writing skills viewed from 
their critical thinking. This finding was the same finding as what Shin et al. (2011), Forman (2014), and Haerazi \& Irawan (2020a) found out. These results claimed that culture-based textbooks in EFL class had developed students' language skills. In this current study of reading activities, students are exposed to various cultural texts. They are requested to read sentences and examine the structure of the sentences. In pairs, they discuss the ideas from the text, recognize the pattern of sentences and paragraphs, and communicate their comprehension. They involve in intercultural communication activities in reading learning activities. It is in accordance with Hoff (2019) who informs that students, who are given English texts in reading, inherently involve process of intercultural interaction, and it contributes to their comprehension of intercultural communication.

During writing exercises, students are requested to produce sentences based on their reading comprehension. In doing so, they are completed with some graphic organizers. Using graphic organizers is important for students at junior high schools. According to Juniarti et al. (2017), a graphic organizer is useful in writing exercises for students to combine their ideas into a complete paragraph. The text type going to create in this current study is a complete descriptive text. The cultural topics provided are enclosed with questions that bring students to think critically before writing. Tables 2 and 3 illustrate interactions and significant differences between teaching materials and critical thinking skills in reading classes and writing classes.

Table 2. Summary of multifactor analysis of variance (ANOVA) in reading classes

\begin{tabular}{lrrrrr}
\hline Source & $\begin{array}{c}\text { Type III Sum of } \\
\text { Squares }\end{array}$ & df & Mean Square & \multicolumn{1}{c}{ F } & \multicolumn{1}{c}{ Sig. } \\
\hline Corrected Model & $4614.266^{\mathrm{a}}$ & 5 & 922.853 & 9.308 & .000 \\
\hline Intercept & 233395.998 & 1 & 233395.998 & 2353.991 & .000 \\
\hline Model & 1461.612 & 1 & 1461.612 & 14.742 & .000 \\
\hline CT & 2502.758 & 2 & 1251.379 & 12.621 & .000 \\
\hline C-BIM * CT & 744.742 & 2 & 372.371 & 3.756 & .030 \\
\hline
\end{tabular}

Table 3. Summary of multifactor analysis of variance (ANOVA) in writing classes

\begin{tabular}{lrrrrr}
\hline \multicolumn{1}{c}{ Source } & $\begin{array}{c}\text { Type III Sum of } \\
\text { Squares }\end{array}$ & df & Mean Square & F & Sig. \\
\hline Corrected Model & $3585.964^{\mathrm{a}}$ & 5 & 717.193 & 11.320 & .000 \\
\hline Intercept & 259809.840 & 1 & 259809.840 & 4100.956 & .000 \\
\hline Model & 1314.469 & 1 & 1314.469 & 20.748 & .000 \\
\hline CT & 1789.402 & 2 & 894.701 & 14.122 & .000 \\
\hline Non-Culture * CT & 426.855 & 2 & 213.427 & 3.369 & .042 \\
\hline
\end{tabular}

Tables 2 and 3 informed that it is significantly different between the C-BIM and non-cultural materials in enhancing students' reading comprehension and writing skills viewed from critical thinking skills. The critical thinking skills also determined the success of students' reading and writing skills at the eighth-grade students at SMPN 1 Jonggat, Central Lombok. It could be stated that it had a significant impact on reading and writing skills. It is supported by some previous studies showing critical thinking has a significant contribution to developing students' language skills such as reading skills (Aghajani \& Gholamrezapour, 2019; Thamrin \& Agustin, 2019; Imran et al., 2019) and writing skills (Sinaga \& Feranie, 2017; Haerazi, Utama, et al., 2020). Furthermore, the acquisition of critical thinking skills in reading and writing 
classes is influenced by the teaching materials and instructional methods or strategies the English teachers applied in classes.

\section{Research question 2: the teachers' intercultural awareness and the students' and teachers' perception on the C-BIM model}

EFL teachers can promote students' reading comprehension and writing skills using the C-BIM model inasmuch as they have great intercultural awareness. They have also completely perceived the use of the C-BIM model employed inasmuch as it can enhance students' English language skills, motivation, engagement, and selfefficacy. Table 4 demonstrates the teachers' intercultural awareness that consists of dimensions of knowledge, attitude, interpretation skill, and cultural practice.

Table 4. Teachers' intercultural awareness

\begin{tabular}{|c|c|}
\hline Themes & Sample Excerpts \\
\hline Knowledge & $\begin{array}{l}\text { "I ask my students to discuss their own cultures such as traditional } \\
\text { arts, games, and technologies. Afterward, I ask them to identify its } \\
\text { values that are perceived by English-speaking people". } \\
\text { "I ask my students to explore different views that Sasaq People and } \\
\text { English-speaking people may have on a similar phenomenon". } \\
\text { "Besides cultures of English-speaking countries, I provide students } \\
\text { with cultures of other countries such as British and American". }\end{array}$ \\
\hline Attitude & $\begin{array}{l}\text { "I ask my students to share what they strange or fascinating dealing } \\
\text { with their own cultures and English-speaking countries". } \\
\text { "I urge students to internalize their own values, beliefs, and views } \\
\text { which are perceived differently by people from other cultures". }\end{array}$ \\
\hline $\begin{array}{l}\text { Skills of interpreting and } \\
\text { relating }\end{array}$ & $\begin{array}{l}\text { "I ask students to interpret the cultural perspectives in a new cultural } \\
\text { context". } \\
\text { "I ask students to explain the new cultural context that they meet" } \\
\text { "I ask students to explore parts of misunderstanding in } \\
\text { communications between Indonesian people and English-speaking } \\
\text { people and elaborate the causes". }\end{array}$ \\
\hline $\begin{array}{l}\text { Skills of discovery and } \\
\text { interaction }\end{array}$ & $\begin{array}{l}\text { "I ask students to integrate what they find out with what they already } \\
\text { have in communicative manners". } \\
\text { "I ask students to build the cultural knowledge into a cultural practice } \\
\text { in communicative manners". } \\
\text { "I ask students to interact with other different cultures in the form of } \\
\text { communicative activities". }\end{array}$ \\
\hline $\begin{array}{l}\text { Critical cultural } \\
\text { awareness }\end{array}$ & $\begin{array}{l}\text { "I ask students to discuss in detail how their own values and beliefs } \\
\text { affect the way they perceive other cultures". } \\
\text { "I ask students to evaluate critically the cultural products and practices } \\
\text { they have met". } \\
\text { "I ask students to share the cultural products and practices from the } \\
\text { cultures of English-speaking countries". }\end{array}$ \\
\hline
\end{tabular}

That the abilities of EFL teachers professed the intercultural dimensions in applying the C-BIM model was able to promote their students' linguistic awareness inasmuch as they internalize and imitate English expressions that they study. Providing with cultural texts helps students enhance reading comprehension (Hoff, 2019). Besides, intercultural activities exhibited in the class help students to improve skills of discovery and interaction. It is corresponding to Fernandez-Aguero and Chancay-Cedeno (2019) who declare that language learners can do a communication representing the balance between how they understand their cultures and how they can relate their local expressions with others from a different culture. In doing so, 
teachers facilitate students with cultural teaching materials (Colaiacomo \& Puntil, 2018; Fernández \& Pozzo, 2017).

Table 4 informed that English teachers at junior high schools have enough intercultural awareness capabilities to apply the culture-based materials to enhance students' reading and writing skills. For instance, in terms of adding students' knowledge, teachers ask students to discuss their own cultures first before starting reading activities. It aims to raise their prior knowledge of the texts. In these activities, students are asked to analyze the topics, explore any parts of the text and the sequences of the text's story. Also, students are asked to explore different perspectives dealing with the provided cultural topics. It leads them to see whether they have a similar cultural value or not. In doing so, teachers provide them with a summarization of the text. Afterward, students are asked to identify the values that are perceived by English-speaking people in pairs and individual activities. Some studies showed these learning activities were capable of developing intercultural competencies (Tambyah, 2018; Fernández-Agüero \& Chancay-Cedeño, 2019; and Hagar \& Hagar, 2018).

In the current study, intercultural awareness plays an important role in implementing the C-BIM model to improve students' reading and writing skills. Another aspect as a moderator variable is a critical thinking skill. The data are underpinned by the students' and teachers' positive perception on the C-BIM model inasmuch as it can help them enhance their language skills, engagement, motivation, and self-efficacy. Table 5 illustrated the students' and teachers' perceptions of using the C-BIM model as a learning strategy to the teaching of reading and writing classes. Their perception was addressed in four aspects: language skills (reading and writing), engagement or collaboration, motivation, and self-efficacy.

Table 5. Students' and teachers' perception on the C-BIM model

\begin{tabular}{|c|c|}
\hline Themes & Sample Excerpts \\
\hline \multirow{2}{*}{$\begin{array}{c}\text { Language skills } \\
\text { (reading and } \\
\text { writing) }\end{array}$} & $\begin{array}{l}\text { "The culture-based teaching positively made us easy to manage my students } \\
\text { because the materials were quite easy for students to understand". } \\
\text { "The various texts for reading activities were very helpful to raise their } \\
\text { linguistic awareness such as vocabulary and grammar to write a simple } \\
\text { sentence and it is used to create a complete paragraph". } \\
\text { "I feel that it can help my students to acquire much more vocabulary, } \\
\text { grammar, and the information of cultures". } \\
\text { [Teachers-focus group interview] }\end{array}$ \\
\hline & $\begin{array}{l}\text { "..I can recognize my own cultures and understand how English language } \\
\text { skills are spoken". } \\
\text { "...It can allow me to analyze any part of sentences and paragraphs so that I } \\
\text { can understand the whole text". } \\
\text { "... When I do reflection of my own cultures, I can see how English-speaking } \\
\text { people understand my cultures. Also, I can comprehend how English } \\
\text { speakers express their English into texts". } \\
\text { [Students-reflective journal] }\end{array}$ \\
\hline \multirow[t]{2}{*}{$\begin{array}{l}\text { Engagement or } \\
\text { collaboration }\end{array}$} & $\begin{array}{l}\text { "I feel this instruction allow me and students to interact much more in } \\
\text { discussion session and reflective phase. It makes the class more interesting } \\
\text { and dynamic learning". } \\
\text { "I think the interaction between students and teacher is active because this } \\
\text { instruction provides them with interesting cultural topics to read and write. } \\
\text { Student already had a prior knowledge and had insight to share in the class". } \\
\text { [Teachers-focus group interview] }\end{array}$ \\
\hline & $\begin{array}{l}\text { "...in reading activities, I think this instruction allow me to work together to } \\
\text { find some words, phrases, or sentences that I do not understand". }\end{array}$ \\
\hline
\end{tabular}




\begin{tabular}{ll}
\hline Themes & Sample Excerpts \\
\hline "...during the group discussion and presentation, this instruction afforded \\
me a chance to use my English and share my ideas to the class". Also, it \\
allows me to arrange my sentences into a complete paragraph". \\
[Students-reflective journal] \\
"... I think this instruction demanded me to prepare my teaching well. It \\
makes me to have good motivation to teach my cultural topics in the class". \\
"...I want to create much more various local cultures that I know as my \\
teaching materials for other skills". \\
[Teachers-focus group interview] \\
"...some reading texts and writing exercises are very exciting for me as I and \\
my group have different perspectives on traditional music values. We can \\
discuss it critically". \\
"....when I do presentation phase, I feel exciting as my group and other \\
groups have different views of local and target cultures to compare. We can \\
express our ideas in a simple paragraph". \\
[Students-reflective journal] \\
"I feel this instruction and teaching materials are easy to do in the class and I \\
believe I can perform it to my students". \\
"...the cultural topics are smoothly understood by me inasmuch as I \\
accomplish learning tasks easily". \\
[Teachers-focus group interview] \\
"I think I am capable of accomplishing all reading activities and writing \\
exercises as some difficult words are listed in the teaching materials". \\
"...I think all reading activities and writing tasks are able to be done because I \\
have good knowledge of contents being discussed, grammar, and \\
vocabulary". \\
[Students-reflective journal]
\end{tabular}

The C-BIM model in practice facilitates students and EFL teachers to organize their learning process. Teachers feel easy to improve students' reading comprehension and writing skills through each activity. This finding accords with some previous studies relating to culture and intercultural language learning in terms of improving language skills (Haerazi \& Irawan, 2020a; Raigón-Rodríguez, 2018; Colaiacomo \& Puntil, 2018; Hagar \& Hagar, 2018; and Fernández-Agüero \& Chancay-Cedeño, 2019). The class teacher directs students to scrutinize each word, phrase, and sentence in prereading activities. In doing so, students are assisted with a vocabulary list. Cultural texts are provided for students to treat students to build their cultural background while recognizing text structures. While they are doing reading activities, they are writing sentences based on their reading comprehension. Reading and writing activities can be integrated using culture-based instruction (Cooney et al., 2018).

Dealing with the engagement, the C-BIM model is highly engaging students in learning activities. Some relevant studies show that reading and writing can engage students in dynamic learning (Albiladi, 2018; Chen, 2018; and Haerazi et al., 2018). For example, the phase of noticing stage involved students in active learning to identify some cultural items of their own cultures and target cultures. The factors influencing students' enthusiasm for learning are various cultural topics. The use of different topics allows students to notice, discuss, compare, and shoot other students' views among group members. In doing so, the teacher plays a role as a facilitator and feedback giver for correcting students' reading comprehension and writing products. Due to this learning, students are easier to acquire vocabulary, grammar, and generic structure of the text. 
In terms of motivation theme, the C-BIM model encourages students to recognize and internalize their own cultures. As students are asked to identify and discuss their own cultures, they sometimes need a longer time to give a response. Fortunately, they can accomplish their reading tasks and create some drafts that are used to complete a descriptive text later on. It shows that they have a good motivation to complete their learning activities. In the discussion session, they are capable of working together to complete writing exercises. Also, teachers supply students with various learning tasks. Teachers feel easy to organize students' own cultures and target cultures in reading activities through various cultural topics. It is in line with Song (2019) who informs that the cultural contents boost students to associate their own knowledge to the target cultures and facilitate them to accommodate cultural knowledge into concrete communication. Besides, they are able to imitate how English speakers express their ideas into written forms (Munandar \& Ulwiyah, 2012; Baker, 2012; and Baker, 2015).

In terms of self-efficacy issues, the C-BIM model's implementation is capable of facilitating students to evolve their self-efficacy. Due to good self-efficacy, students are able to accomplish their reading and writing learning on time. In the learning process, students are asked to perform reading activities at a particular time. Surprisingly, they can finalize their tasks in accordance with the enacted time. Besides, the C-BIM model allows students to encourage collaborative learning activities. It escalates students' language fluency and readiness. In groups, students feel easy to acquire new vocabulary from their partners and teachers' feedback. Due to these activities, the teacher feels easy to promote students' self-confidence and self-efficacy to accomplish their learning assignments inside and outside classes. It is in line with some previous studies reporting that students' partnership and teachers' participation can improve students' self-efficacy and motivation (Burić \& Kim, 2020; Cave et al., 2018; and Mali, 2017).

\section{CONCLUSION}

This study has provided empirical evidence on the meaningful insertion and implementation using culture-based instructional materials in improving reading and writing skills. Another aspect of this study is critical thinking skills affecting the students' reading and writing skills. The findings show that culture-based materials positively contribute to pre-reading processes, whilst-reading, and post-reading activities. Also, students can realize their reading comprehension in a complete descriptive paragraph. Through cultural instruction, students can acquire and enhance their linguistic, cognitive, and sociocultural competencies. It promotes students to develop reading and writing skills, motivation, engagement, and selfefficacy. The teaching steps of intercultural instruction also help students conduct noticing, comparing, and reflecting activities to build their own cultural knowledge and the target cultures. Therefore, students feel easy to comprehend English texts, and they are able to generate a complete descriptive text.

Drawing on this study's weaknesses, future English teachers should provide more cultural materials for creation of reading and writing exercises in terms of using their critical thinking skills. In designing learning tasks, future instructors must consider the various cultural topics to encourage students to acquire reading and writing skills and improve collaborative activities in pairs and groups. It is strongly 
recommended that another empirical study with a culture-based instructional model be conducted in English for Specific Purpose (ESP) classes.

\section{RECOMMENDATION}

The development of C-BIM model encourages students to activate their background knowledge since they do reading activities. In doing this, the future studies need to provide students with various reading texts or materials. Afterwards, English teachers bring students into writing exercises. The implementation of the CBIM model is highly recommended to be done using technology to improve language skills, namely listening, speaking, reading, and writing skills. In short, the current study is the catalyst for future studies in inserting and reflecting local cultures in ELT textbooks. Besides, further studies should pay attention to the prospective teachers' intercultural competences on how English native speakers express their ideas in papers because sociolinguistics relates to cultures and the target language in societies. Lastly, the practitioners need to explore other language learning models to underpin the self-regulated metacognitive strategy in teaching other language skills (speaking, reading, and listening skills)

\section{ACKNOWLEDGMENT}

Researchers would like to thank the rector of STAIN Metro for providing research grant to carry out research activities. Researchers also expresses the deepest appreciation and gratitude to English lectures from Iran, Magelang (Central Java), and Mataram West Nusa Tenggara in collaboration with ALTI researcher groups.

\section{REFERENCES}

Ab Kadir, M. A. (2018). An inquiry into critical thinking in the Australian curriculum: examining its conceptual understandings and their implications on developing critical thinking as a "general capability" on teachers' practice and knowledge. Asia Pacific Journal of Education, 38(4), 533-549. https:/ / doi.org/10.1080/02188791.2018.1535424

Aghajani, M., \& Gholamrezapour, E. (2019). Critical thinking skills, critical reading and foreign language reading anxiety in Iran context. International Journal of Instruction, 12(4), 219-238. https:/ / doi.org/10.29333/iji.2019.12414a

Albiladi, W. S. (2018). Exploring the Use of Written Authentic Materials in ESL Reading Classes: Benefits and Challenges. English Language Teaching, 12(1), 67. https:/ / doi.org/10.5539/elt.v12n1p67

Aprianoto, \& Haerazi. (2019). Development and assessment of an interculture-based instrument model in the teaching of speaking skills. Universal Journal of Educational Research, 7(12), 2796-2805. https:/ / doi.org/10.13189/ujer.2019.071230

Baker, W. (2012). From cultural awareness to intercultural awareness: Culture in ELT. ELT Journal, 66(1), 62-70. https://doi.org/10.1093/elt/ccr017

Baker, W. (2015). Culture and identity through English as a lingua Franca: Rethinking concepts and goals in intercultural Communication. Culture and Identity through English as a Lingua Franca: Rethinking Concepts and Goals in Intercultural Communication, 8678, 1-284. https://doi.org/10.1093/elt/ccx022

Burić, I., \& Kim, L. E. (2020). Teacher self-efficacy, instructional quality, and student motivational beliefs: An analysis using multilevel structural equation modeling. 
Learning and Instruction, 66(December 2019), 101302. https://doi.org/10.1016/j.learninstruc.2019.101302

Cave, P. N., Evans, N. W., Dewey, D. P., \& Hartshorn, K. J. (2018). Motivational partnerships: increasing ESL student self-efficacy. ELT Journal, 72(1), 83-96. https://doi.org/10.1093/elt/ccx027

Chen, I. C. (2018). Incorporating task-based learning in an extensive reading programme. ELT Journal, 72(4), 404-414. https://doi.org/10.1093/elt/ccy008

Cohen, L., Manion, L., \& Morrison, K. (2018). Research Methods in Education (8th Edition). New York: Routledge.

Colaiacomo, S., \& Puntil, D. (2018). Intercultural Learning - An undergraduate module supporting the development of students' cultural awareness in international settings. Language Learning in Higher Education, 8(1), 187-196. https://doi.org/10.1515/cercles-2018-0011

Cooney, A., Darcy, E., \& Casey, D. (2018). Integrating reading and writing: Supporting students' writing from source. Journal of University Teaching and Learning Practice, 15(5).

Creswell, J. W., \& Creswell, J. D. (2018). Research Design: Qualitative, Quantitative, and Mixed Methods Approaches (Fifth Edition). In Journal of Chemical Information and Modeling (Vol. 53, Issue 9). Los Angeles: Sage Publication. https:// doi.org/https://lccn.loc.gov/2017044644

Dinh, T. N., \& Sharifian, F. (2017). Vietnamese cultural conceptualisations in the locally developed english textbook: A case study of 'lunar new year'/ 'tet.' Asian Englishes, 19(2), 148-159. https:/ / doi.org/10.1080/13488678.2017.1279763

Espey, M. (2018). Enhancing critical thinking using team-based learning. Higher Education Research and Development, 37(1), 15-29. https://doi.org/10.1080/07294360.2017.1344196

Fernández-Agüero, M., \& Chancay-Cedeño, C. (2019). Interculturality in the Language Class - Teachers' Intercultural Practices in Ecuador. RELC Journal, 50(1), 164-178. https:// doi.org/10.1177/0033688218755847

Fernández, S. S., \& Pozzo, M. I. (2017). Intercultural competence in synchronous communication between native \& non-native speakers of Spanish. Language Learning in Higher Education, 7(1), 109-135. https:// doi.org/10.1515/cercles2017-0003

Forman, R. (2014). How local teachers respond to the culture and language of a global English as a Foreign Language textbook. Language, Culture and Curriculum, 27(1), 72-88. https:/ / doi.org/10.1080/07908318.2013.868473

Haerazi, H., \& Irawan, L. A. (2020a). Developing Intercultural Language Learning (ILL) model to teach writing skills at Indonesian private universities. EduLite: Journal of English Education, Literature and Culture, 5(1), 43. https://doi.org/10.30659/e.5.1.43-54

Haerazi, H., Irawan, L. A., Suadiyatno, T., \& Hidayatullah, H. (2020). Triggering preservice teachers ' writing skills through genre-based instructional model viewed from creativity. International Journal of Evaluation and Research in Education, 9(1), 234-244. https://doi.org/10.11591/ijere.v9i1.203945

Haerazi, H., May Vikasari, R., \& Prayati, Z. (2019). The Use of Scientific-Based Approach in ELT Class to Improve Students' Achievement and Classroom Interaction. Register Journal, 12(2), 157-180. https://doi.org/10.18326/rgt.v12i2.157-180 
Haerazi, H., Utama, I. M. P., \& Hidayatullah, H. (2020). Mobile Applications to Improve English Writing Skills Viewed from Critical Thinking Ability for PreService Teachers. International Journal of Interactive Mobile Technologies (IJIM), 14(07), 58. https:// doi.org/10.3991/ijim.v14i07.11900

Haerazi, \& Irawan, L. A. (2020b). The effectiveness of ECOLA technique to improve reading comprehension in relation to motivation and self-efficacy. International Journal of Emerging Technologies in Learning, 15(1), 61-76. https://doi.org/10.3991/ijet.v15i01.11495

Haerazi, Irwansyah, D., Juanda, \& Azis, Y. A. (2018). Incorporating intercultural competences in developing English materials for writing classes. Journal of Language Teaching and Research, 9(3), 540-547. https:/ / doi.org/http://dx.doi.org/10.17507/jltr.0903.13

Hagar, T. J., \& Hagar, T. J. (2018). Role of Reflective Knowledge in the Development of Intercultural Competence Intercultural Competence. Journal of Intercultural Communication Research, 5759, 1-18. https:/ / doi.org/10.1080/17475759.2018.1427615

Hamiddin, \& Saukah, A. (2020). Investigating metacognitive knowledge in reading comprehension: The case of Indonesian undergraduate students. Indonesian Journal of Applied Linguistics, 9(3), 608-615. https://doi.org/10.17509/ijal.v9i3.23211

Haryati, S., \& Hidayati, D. N. (2017). Hoax News: Promoting the Students' Critical Thinking in Critical Reading Class. Register Journal, 10(2), 122. https:/ / doi.org/10.18326/rgt.v10i2.122-139

Hoff, H. E. (2019). Fostering the "Intercultural Reader"? An Empirical Study of SocioCultural Approaches to EFL Literature. Scandinavian Journal of Educational Research, 63(3), 443-464. https:// doi.org/10.1080/00313831.2017.1402366

Imran, F., Firman, E., \& Raudhatunnisa, S. (2019). Applying think-talk-write (TTW) in the teaching of reading comprehension in relation to students' critical thinking skills. JOLLT Journal of Languages and Language Teaching, 7(1), 57. https:/ / doi.org/10.33394/jollt.v7i1.1439

Januarty, R.-. (2018). Extensive Reading (ER) Practices and the Development of $\begin{array}{llll}\text { Language Fluency. } & \text { Lingua }\end{array}$ https:/ / doi.org/10.21512/lc.v12i3.4063

Juniarti, K., Sofyan, D., \& Kasmaini. (2017). the Effect of Using Graphic Organizer To Students' Writing Ability. Journal of English Education and Teaching, 1(1), $48-$ 57. https:// doi.org/10.33369/jeet.1.1.48-57

Krulatz, A., Steen-Olsen, T., \& Torgersen, E. (2018). Towards critical cultural and linguistic awareness in language classrooms in Norway: Fostering respect for diversity through identity texts. Language Teaching Research, 22(5), 552-569. https:/ / doi.org/10.1177/1362168817718572

Kusumaningputri, R., \& Widodo, H. P. (2018). Promoting Indonesian university students' critical intercultural awareness in tertiary EAL classrooms: The use of digital photograph-mediated intercultural tasks. System, 72, 49-61. https:/ / doi.org/10.1016/j.system.2017.10.003

Listyani, L. (2017). Academic Writing Students' Affective Reactions towards Joint Reconstruction Phase of Reading to Learn. Celt: A Journal of Culture, English $\begin{array}{lllll}\text { Language } \quad \text { Teaching } \quad \text { \& } & \text { Literature, }\end{array}$ https:/ / doi.org/10.24167/ celt.v17i2.1206 
Liu, F., \& Stapleton, P. (2018). Connecting writing assessment with critical thinking: An exploratory study of alternative rhetorical functions and objects of enquiry in writing prompts. Assessing Writing, 38(September), 10-20. https:/ / doi.org/10.1016/j.asw.2018.09.001

Low, E. L., Hui, C., \& Cai, L. (2017). Developing student teachers' critical thinking and professional values: a case study of a teacher educator in Singapore. Asia Pacific Journal of Education, 37(4), 535-551. https:/ / doi.org/10.1080/02188791.2017.1386093

Mali, Y. C. G. (2017). Motivational Teaching Strategies in Indonesian EFL Writing Classrooms. Celt: A Journal of Culture, English Language Teaching \& Literature, 17(1), 60. https:/ / doi.org/10.24167/celt.v17i1.1139

Manshaee, G., Dastnaee, T. M., Seidi, A., \& Davoodi, A. (2014). Comparison of critical thinking in students interested and uninterested in learning a second language. Theory and Practice in Language Studies, 4(4), 792-799. https:/ / doi.org/10.4304/tpls.4.4.792-799

McConachy, T. (2018). Critically engaging with cultural representations in foreign language textbooks. Intercultural Education, 29(1), 77-88. https:/ / doi.org/10.1080/14675986.2017.1404783

McConachy, T., \& Hata, K. (2013). Addressing textbook representations of pragmatics and culture. ELT Journal, 67(3), 294-301. https:/ / doi.org/10.1093/elt/cct017

Munandar, M. I., \& Ulwiyah, I. (2012). Intercultural approaches to the cultural content of Indonesia ' s High School ELT textbooks. Cross-Cultural Communication, 8(5), 67-73. https:/ / doi.org/10.3968/j.ccc.1923670020120805.975

Nerim, N. (2020). Scrutinizing Directed Reading thinking activity (DRTA ) Strategy on Students' Reading Comprehension. JOLLT Languages and Language Teaching, 8(2), 128-138. https:// doi.org/10.33394/jollt.v8i2.2284

Novita, D. (2018). Syndicate Learning: an Alternative Approach for Teaching Extensive Reading. Journal of Languages and Language Teaching, 6(1), 27. https:/ / doi.org/10.33394/jollt.v6i1.810

Rahmawati, H. (2019). The Students' Perception on Academic Reading Log for Essay Writing Literacy: Some Influential Points. JEES (Journal of English Educators Society), 4(1), 66. https:/ / doi.org/10.21070/jees.v4i1.1948

Raigón-Rodríguez, A. (2018). Analysing cultural aspects in EFL textbooks: A skillbased analysis. Journal of English Studies, 16, 281-300. https:/ / doi.org/10.18172/jes.3478

Shin, J., Eslami, Z. R., \& Chen, W. C. (2011). Presentation of local and international culture in current international English-language teaching textbooks. Language, Culture and Curriculum, 24(3), 253-268. https:/ / doi.org/10.1080/07908318.2011.614694

Sinaga, P., \& Feranie, S. (2017). Enhancing critical thinking skills and writing skills through the variation in non-traditional writing task. International Journal of Instruction, 10(2), 69-84. https:// doi.org/10.12973/iji.2017.1025a

Song, B. (2019). Exploring the cultural content in Chinese ELT textbooks from intercultural perspectives. Journal of Asia TEFL, 16(1), 267-278. https:/ / doi.org/10.18823/asiatefl.2019.16.1.17.267

Song, H. (2013). Deconstruction of cultural dominance in Korean EFL textbooks. Intercultural Education, 24(4), 382-390. https:/ / doi.org/10.1080/14675986.2013.809248 
Sumekto, D. R. (2018). Investigating the Influence of Think-Pair-Share Approach toward Students' Reading Achievement. Lingua Cultura, 12(2), 195. https:/ / doi.org/10.21512/lc.v12i2.4011

Tambyah, M. (2018). Intercultural understanding through a ' similar but different ' international teaching practicum. Teaching Education, 6210, 1-18. https:/ / doi.org/10.1080/10476210.2018.1453795

Tan, L. S., Koh, E., Lee, S. S., Ponnusamy, L. D., \& Tan, K. C. K. (2017). The complexities in fostering critical thinking through school-based curriculum innovation: research evidence from Singapore. Asia Pacific Journal of Education, 37(4), 517534. https:/ / doi.org/10.1080/02188791.2017.1389694

Thamrin, N. R., \& Agustin, S. (2019). Conceptual variations on reading comprehension through higher order thinking skills (HOTS) strategy. ENGLISH REVIEW: $\begin{array}{llll}\text { Journal of English } & \text { 7(2). }\end{array}$ https:/ / doi.org/10.25134/erjee.v7i2.1777.Received

Thompson, C. C., \& Patterson, J. (2019). Promoting Critical Thinking in an Online Certificate Program For Faculty in the Health Professions. American Journal of Distance Education, 33(1), 71-84. https:/ / doi.org/10.1080/08923647.2019.1555304

Uzum, B., Yazan, B., \& Selvi, A. F. (2018). Inclusive and exclusive uses of we in four American textbooks for multicultural teacher education. Language Teaching Research, 22(5), 625-647. https:/ / doi.org/10.1177/1362168817718576

Wei, L. (2014). College English Network Teaching and Learning Model Oriented by Critical Thinking Problems through Community of Practice. Theory and Practice in Language Studies, 4(12), 2485-2491. https://doi.org/10.4304/tpls.4.12.24852491

Wiles, J. L., Allen, R. E. S., \& Butler, R. (2016). Owning my thoughts was difficult: Encouraging students to read and write critically in a tertiary qualitative research methods course. Journal of University Teaching and Learning Practice, 13(1).

Yuan, R., \& Stapleton, P. (2020). Student teachers' perceptions of critical thinking and its teaching. ELT Journal, 74(1), 40-48. https:// doi.org/10.1093/elt/ccz044 